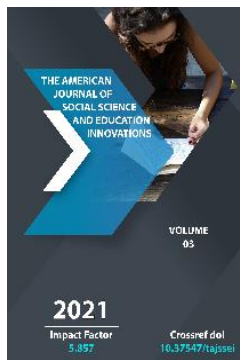

\title{
Linguistic Features Of The Conditional Field In Uzbek Language
}

\author{
Azizakhon Rasulova \\ Doctor Of Philosophy In Philological Sciences (PhD), Fergana State University, Fergana, \\ Uzbekistan
}

Journal Website:

http://usajournalshub.c

om/index,php/tajssei

Copyright: Original

content from this work

may be used under the

terms of the creative

commons attributes

4.0 licence.

\section{ABSTRACT}

This article discusses the functional-semantic field, the functional-semantic field, the characteristics of the form and content of language vocalization, conditional units, the relationship of conditional relations to other meanings, the relationship of mapping and boundary meaning, units from the core and periphery of conditional space.

\section{KEYWORDS}

Field, functional-semantic field, conditional relationship, conditional field, central and boundary meaning, condition and time, core, periphery

\section{INTRODUCTION}

Society is evolving, and language is evolving. Recently, in our linguistics, the study of linguistic phenomena is taking place in a new direction. In this sense, the idea of Professor N. Mahmudov that "language is a multifunctional phenomenon, the essence of a single beep cannot be determined by focusing on its specific beep function" [4, pp. 3-16] is noteworthy. 
It is well known that the peculiarity of systematic research is that it does not approach linguistic facts autonomously, but focuses on the discovery of the essence under which the pill lies. The researcher's focus is more on illuminating the relationship between linguistic phenomena. According to H.Usmanova, except for the phonological level of the language, all the levels of the language are a complex device consisting of the relationship of form and content. Therefore, one of the important tasks of system linguistics is to study both sides of the linguistic units belonging to these levels, to determine their relationship [7, pp. 49-59]. In Uzbek linguistics, special attention is paid to the study of linguistic phenomena on the basis of field theory, and serious research has been conducted in this area, and this work continues. Indeed, the study of any language as a field provides a great help in fundamentally closing the dialectical relationship of the universe-mind-language.

\section{THE MAIN FINDINGS AND RESULTS}

The unification of linguistic units into specific paradigms based on a specific unifying meaning later gave rise to field theory in linguistics [2, p. 152]. The concept of field came into linguistics from the natural sciences, referring to the area where a physical event occurred and its effects were felt. In linguistics, too, field theory has its own aspects, which cover a variety of areas.

A semantic field is a set of semantic units that have similarities noted in a particular semantic layer and are associated with specific semantic relationships. The semantic field is a large system-structural unit of the lexical-semantic system of language. It combines not only individual linguistic elements (individual lexemes, lexical-semantic variants), but also different lexical paradigms on the basis of common integral signs, and thus each unit of space is reflected in it in the whole paradigmatic complex [13].

The concept of the grammatical field entered linguistics in the 6os and 70s of the twentieth century. V.G.Admoni, M.M.Guxman, E.V.Guliga, E.I.Shendels, A.V.Bondarko and other scientists conducted research related to the functional-semantic field.

The concept of functional-semantic field reflects the phenomenon of interaction of elements of different language levels, which fully manifests itself in speech. However, the system-linguistic basis of such units as functional-semantic field lies in the core of the grammatical structure of the language itself, in the core of grammatical categorization. This core does not exist as an abstract "pure grammatical framework (basis)" but includes inter-level paradigmatic aspects of different levels of grammatical-lexical coherence, relationships, and interactions.

Functional-semantic field is a two-way (semantic-formal) formed by the interaction of grammatical (morphological and syntactic) means of the language with lexical, lexicalgrammatical and word-forming elements belonging to the same semantic zone is unity $[1$, p. 40].

Hence, the functional-semantic field unites both lexical-semantic units and grammatical units in the language system based on the principle of content to form.

An analysis of the views on the linguistic field created in recent years in world linguistics shows that there are different interpretations of the phenomena considered as a field. In 
particular, in Uzbek linguistics, a lot of serious research on field theory is carried out. In each of these works, the generalization of semantics into one archetype, grouping under different integral semantics and specificity with differential semantics has been studied.

Units denoting conditional relations are available in all languages of the world. These units have been studied not only in linguistics, but also in psychology, logic and philosophy, as well as in the sciences that study language and speech from different perspectives and perspectives. It is no coincidence that the units that represent the meaning of a condition are defined as "assumptions (assumptions) close to reality". This is because the units that represent the conditional relationship are also recognized as a specific "key" that allows them to uncover some of the mysteries of speech activity [5, p. 175].

The peculiarity of the units that give rise to a conditional relationship is that they are directly a " The peculiarity of the units which give rise to the conditional relation is that they directly select one of the two possibilities which contradict each other; to be able to reason on the basis of incomplete information, to draw conclusions on the basis of a "condition" that may exist between different situations, and, if this condition is met, to understand that "the world will change" specifically reflects. That is, if the weather is cloudy, the possibility of "rain" or "no rain" appears as a result of the statement that it will rain. When the condition of cloudy weather is the result of rain, the state of "changing the world" causes the air to be cleared of dust, the earth to bleed, the plants to be nourished, or, conversely, the result of this condition. The state of "changing the world" also changes in the opposite direction, drought of the land, thirst of plants, and so on.
There are certain experiments in the study of conditional meaning in world linguistics. In particular, conditional tenses, separate types of compound sentences, as well as their functional-syntactic synonymous series, expression of conditional-result semantics within simple sentences, comparative analysis of constructions expressing conditional meaning, some aspects of conditional category; more precisely, the names of P.P.Rogojnikova, M.C.Guricheva, E.I.Korotaeva, A.V.Bogomolova, L.D.Kabzan, P.M.Teremova, G.V.Razvina, M.Kubik, A.P.Slivkov, V.C. Khrakovsky, etc., who conducted research on the problem of studying this category.

According to P.M. Teremova, who conducted research on the category of a condition and its function at the grammatical level, the category of a condition that forms the center of the conditional field represents a complex multilevel system. The occurrence of a condition can be seen in two different ways in terms of certainty and uncertainty: 1) with the meaning of a real condition; 2 ) in the sense of an unreal condition, i.e., when the condition is not fulfilled, the condition and the result are expressed as an action that does not take place (or cannot take place). P.M. Teremova also mentions that both the real condition and the unreal condition have their own micro-field, their own nucleus and periphery [9, p. 52].

A.P. Slivkov's research analyzes the study of the condition category at the syntactic level as an integral part of the condition area. The subject of the researcher's dissertation is a set of tools for expressing conditional relations in Russian. In his view, the conditional category is one of the functional-semantic categories, and it is important, first of all, from a pragmatic point of view. The scientist recommends 
studying the expression of a conditional relationship as a real conditional situation and an unreal conditional situation. These situations, in turn, suggest that active speakers should be trained separately for speech and for receptive learners.

"For each semantic circle, its own microfield, which is compatible with nuclear and peripheral means, is important," says A.P. Slivkov. - "In the central part of the microdistricts, a separate nuclear layer is allocated on the basis of the meaning and degree of differentiation of the structures that form the condition category. The constructions located in the core of the conditional space make it convenient for learners of Russian as a foreign language" [8, p. 33].

A comparative analysis of the conditional relationship in Russian with other languages is also seen in the research of V.C. Khrakovsky. In his work, the scientist considers the connection between conditional and temporal relations in conditional sentences. However, it distinguishes between their nuclear and peripheral structure [12].

B.K. Osmanova has a comparative approach to the units representing the conditional relationship. The scientist also distinguishes conditional constructions in speech (mainly in the example of conditional tenses) as a system. He compares such constructions in the Kumyk language with similar constructions in other Turkic languages, including Russian and English, and also pays attention to their semantic, typological and formal aspects.

B.K. Osmanova also comments on the role of conditional mood in the language system as a modal meaning and grammatical meanings in speech, the expression of modal meaning in syntactic constructions of conditional mood and the relationship of conditional tense. He also compares the conditional tenses in the Kumyk language with the conditional tenses in Uzbek, Nogai, Karachay-Bulgarian, Azerbaijani, Karakalpak, Tajik, Kyrgyz, Kazakh, Tatar, Uyghur, Turkmen and other Turkic languages. . Synthetic forms under the formula "may be" or "may not be" exist in Karachay-Bulgarian and Uzbek, but there are no such forms in the Kumyk language. Also, the form of interrogation in the Kumyk language is not formed in the same way as in the Uzbek language", the scientist said in his research [5, p. 175].

There are a number of researches in our linguistics on the expression of conditional relations in Uzbek. The works of A.Azizova, M.Askarova, F.Ubaeva, A.Tsalkalamanidze, A.Mamajonov, G.Rozikova and others are noteworthy. These scholars have paradigmatically studied the units in the position of conditional, conditional, and adverbial conjunctions. However, in linguistics, research on the interdependence of the meanings of condition and barrier and their approach as a field, the Central and boundary semantics of the conditional field, the additional meanings of units representing the conditional meaning has not been studied monograph.

In traditional linguistics, the meaning of the unreal condition in the Uzbek language has also been studied by Yu.Saidov in the context of the verb family. In his article, the researcher argues that the meaning of an unreal condition can be expressed not only conditionally, but also by other means, and explains and gives examples such as -ganda edi, -sa edi, -gan bo'lsa edi, -yotgan bo'lsa edi, -digan bo'lsa edi. However, it compares the Real and Unreal condition to each other. Considers the relation 
of the unreal condition to the verb tenses. The researcher believes that the category of time does not matter for it to be an unreal condition.

Yu.Saidov cites the means of giving the meaning of an unreal condition under the name of "perifrastic forms" and considers their connection with the modal relations of request, advice, desire, command, hypothesis and others.

Speaking about the stylistics of compound sentences, A. Mamajonov focuses on the syntactic and poly-semantic relations between them. In the works of the scientist the synonymy of connectives in conditional and unobstructed adverbs, synonymy and polyfunctionality of compound sentences expressing the content of the condition are analyzed [3, p. 110]. G. Rozikova's research also focuses on the poly-semantic use of sentences, thinking about the ambiguity of conjunctions with conjunctions and adverbs. These statements are poly-semantically modeled [6, p. 24].

It is known that the functional-semantic field is a hierarchical structure of language units that are united on the basis of a common content and express a certain concept in the language. At the center of each functional-semantic field lies a certain semantic category that unites different language tools and creates their interdependence. Based on the above considerations, the conditional field can be defined as follows: The sum of the units of relations expressed by different means based on the conditional content in objective reality is called the conditional field.

The functional-semantic field reflects all the features of the means and forms of language under one commonality in two ways, that is, in terms of form and content. Central and boundary semantic relations are important for the structure of the functional-semantic field. From the center of the field are the most commonly used language units in the representation of a particular semantic category.

"The units that make up the center (core) of a field, and are uniquely designed to represent that field character, are also a minority in all types of fields. Other functionaries tend to move away from this center according to the level of character expression, so they are more exposed to the influence of neighboring centers" [10, p. 96].

While many linguistic units in the conditional field express the meaning of a condition, they also indicate a barrier. It follows that these units also occupy a place in the barrier field as they express this meaning.

\section{CONCLUSION}

It should be noted that the meaning of a condition is often related to a time relation. That is, the realization of a particular "conditional" action or situation definitely requires a time category.

Hence, the combination of language means with different expressions under the general conditional content constitutes a conditional field. At the core of the conditional space are language tools that express the meaning of the condition in the center. At the morphological level, conditional conjunctions and conditional conjunctions, and at the syntactic level, conditional conjunctions are important. On the periphery of the field are the units that represent the condition as a boundary sema. These units, in turn, may be located in the Central part of other semantic fields and may represent the conditional semaphore as an 
The American Journal of Social Science and Education Innovations

(ISSN - 2689-100x)

Published: April 22, 2021 | Pages: 104-110

Doi : https://doi.org/10.37547/tajssei/Volume03lssue04-16

2021: 5.857

additional or partial meaning in the "shadow" of other semantic meanings.

\section{REFERENCES}

1. Bondarko A.V. (2007). Principles of functional grammar and aspects of aspectology. - Moscow: LKI Publishing House. - p. 40. (Бондарко А.В. Принципы функциональной грамматики и вопросы аспектологии. - Москва: Издательство ЛКИ, 2007. -С. 40.)

2. Iskandarova Sh. (2007). Field-based approach to the language system. Tashkent: Fan. - p. 152. (Искандарова Ш. Тил системасига майдон асосида ёндашув. -Тошкент: Фан, 2007. -Б.152.)

3. Mamajonov A. (1990). Compound sentence stylistics. -Tashkent: Fan. - p. 110. (Мамажонов А. Қўшма гап стилистикаси. -Тошкент: Фан, 1990. - Б. 110.)

4. Mahmudov N. (2012). Looking for ways to study the language perfectly ... // Uzbek language and literature. - Tashkent. - № 5. pp. 3-16. (Махмудов Н. Тилнинг мукаммал тадқиқи йулларини излаб... // Ўзбек тили ва адабиёти. - Тошкент, 2012. - № 5. - Б. 316.)

5. Osmanova B.K. (2005). Conditional mood of the Kumyk verb in comparativecomparative lighting // candidate of philological sciences // - Makhachkala: - p. 175.//new dissertation.com spage / cat / idc / 303 / s / 2 / st / ... (Османова Б.К. Условное наклонение кумыкского глагола в сравнительно-сопоставительном освещении// кандидат филологических наук// Махачкала, 2005 г. С. 175.// newdissertation.com page/cat/idc/303/s/2/st/...)

6. Roziqova G. (1999). Syntactic polysemy in Uzbek language: Candidate of Philological Sciences. - Tashkent: - p. 24. (Розиқова Г.
Ўзбек тилида синтактик полисемия: Филол. фанлари номзоди дисс. автореф. Тошкент. 1999. -Б. 24.)

7. Saidov Yu. (1971). Forms of the verb expressing unreality in the modern Uzbek language // Soviet Türkology. - Baku. №1. рр. 49-59. (Саидов Ю. Формы глагола, выражающие нереальность в современном узбекском языке// Совесткая тюркология. -Баку, 1971. №1. C.49-59.)

8. Slivkov A.P. (1998). Improving the skills of expressing conditional relationships in the Russian speech of foreign trainees (in the context of short-term training). Abstract of thesis. Candidate of Pedagogical Sciences. St. Petersburg: - p. 33. (Сливков А.П. Совершенствование навыков выражения условных отношений в русской речи иностранных стажеров (в условиях краткосрочного обучения). Автореф. канд. дисс.. педагогических наук. - СанктПетербург, 1998. -С. 33.)

9. Teremova P.M. (1988). Condition category in functional and grammatical aspect. Leningrad: Publishing house of Leningrad State Pedagogical Institute named after A.I. Herzen. - p. 52. (Теремова Р.М. Категория условия в функциональнограмматическом аспекте. -Л.: Изд-во ЛГПИ им. А.И.Герцена, 1988. - 52 с.)

10. Umarova N. (2016). Semantic and constructive forms of the relationship of cause and effect in the praise of Navoi's ghazals. - Tashkent: Akademnashr. - p. 96. (Умарова Н. Навоий ғазаллари мақтасида сабаб ва оқибат муносабатининг мазмуний хамда конструктив шакллари. Тошкент: Akademnashr, 2016. - Б. 96.)

11. Usmonova X.Sh. (2007). Positional study of parts of speech in the Uzbek language: Diss. Doctor of Philological Sciences. -Tashkent. 
- p. 35. (Усмонова Х.Ш. Ўзбек тилидаги гап бўлакларининг позицион тадқиқи: Филол. фанлари д-ри...дисс.автореф. -Тошкент, 2007. -Б.35)

12. Khrakovsky V.S. (1998). Theoretical analysis of conditional constructions (semantics, calculus, typology). Typology of conditional constructions. Edition. V. S. Khrakovsky. Saint Petersburg. (Храковский В.С. Теоретический анализ условных конструкций (семантика, исчисление, типология) //Типология условных конструкций //Отв. Ред. В.С.Храковский. СПб., 1998.)

13. https://moluch.ru/archive/107/25694/

14. Rasuljanovna, I. N. (2019). Lacunas Occurance In Semantic Fields Of Chinese And Uzbek Languages. International Journal of Scientific \& Technology Research, 8(11), 1998-2001. 